\begin{tabular}{c|c|c|} 
CRITICAL & $\begin{array}{l}\text { Western Ghats } \\
\text { EARTNERSHIP FUND }\end{array}$ & $\begin{array}{c}\text { Special Series } \\
\text { Special Section }\end{array}$ \\
\cline { 2 - 3 } & Meghamalai special section \\
\cline { 3 - 4 } & &
\end{tabular}

\title{
StATUS OF REPTILES IN MEghaMALAI AND ITS ENVIRONS, WESTERN GHATS, TAMIL NADU, INDIA
}

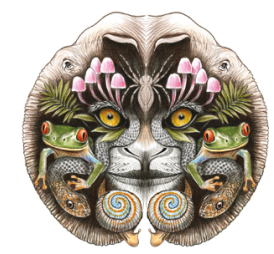

ISSN

Online 0974-7907 Print 0974-7893

OPEN ACCESS

\author{
Subramanian Bhupathy ${ }^{1} \&$ N. Sathishkumar ${ }^{2}$ \\ 1,2 Sálim Ali Centre for Ornithology and Natural History, Anaikatti (PO), Coimbatore, Tamil Nadu 641108, India \\ ${ }^{1}$ bhupathy.s@gmail.com (corresponding author), ${ }^{2}$ sathis.tri@gmail.com
}

\begin{abstract}
We update the reptile fauna of Meghamalai area, Western Ghats based on a literature review and a recent study (2006-2008) by SACON. In all, 90 species of reptiles belonging to 53 genera and 14 families were reported from this area, which include 30 (33.3\%) species endemic to the Western Ghats. Reptiles of the area shared distribution with all biogeographic zones of India, barring the TransHimalaya. High species richness in Meghamalai is due to its broader elevation width, presence of both windward and leeward zones and a variety of forest types. Studies conducted after 2006 added severa species to the faunal list of the area, but could not record 16 species reported earlier including Hutton's Pit Viper, Tropidolaemus huttoni and the Blue-bellied Tree Skink Dasia subcaeruleum from the area since 1949. Numerically, several species are currently rare, and changes in land use and land cover could have led to reduction in their abundance and local extinction. It is hoped that the recently declared Meghamalai Wildlife Sanctuary would reduce further degradation of habitats and help conserve biodiversity. Further studies are needed for understanding the ecology of the several species of reptiles found in this and the nearby areas of the Western Ghats.
\end{abstract}

Keywords: Abundance, endemic species, reptile distribution, threat status, Western Ghats.
Meghamalai (also known as High Wavy Mountains) has been sporadically surveyed for reptiles during the $19^{\text {th }}$ and early $20^{\text {th }}$ centuries by Harold S. Ferguson (1880-1904) and Angus F. Hutton (1946-48). These surveys resulted in the description of new species such as Ashambu Shieldtail Uropeltis liura, Periyar Shieldtail Uropeltis arcticeps madurensis, Striped Narrow-headed Snake Xylophis stenorynchus, Hutton's Pit Viper Tropidolaemus huttoni and Blue-bellied Tree Skink Dasia subcaeruleum. Specimens collected during the above surveys have been deposited at the British Museum Natural History (now the Natural History Museum, London) and in the museum of the Bombay Natural History Society, Mumbai. David \& Vogel (1998) and Hutton \& David (2009) re-examined the collections made by Hutton. Until recently, no serious attempt has

DOI: http://dx.doi.org/10.11609/JoTT.03595.4953-61 | ZooBank: urn:Isid:zoobank.org:pub:576D340A-EOC5-495D-90B0-B5F827891041

Editor: Raju Vyas, Vishwamitri River Project, Vadodara, India.

Date of publication: 26 November 2013 (online \& print)

Manuscript details: Ms \# 03595 | Received 26 April 2013 | Final received 09 August 2013 | Finally accepted 28 October 2013

Citation: Bhupathy, S. \& N. Sathishkumar (2013). Status of reptiles in Meghamalai and its environs, Western Ghats, Tamil Nadu, India. Journal of Threatened Taxa 5(15): 4953-4961; http://dx.doi.org/10.11609/JoTT.03595.4953-61

Copyright: (c) Bhupathy \& Sathishkumar 2013. Creative Commons Attribution 3.0 Unported License. JoTT allows unrestricted use of this article in any medium, reproduction and distribution by providing adequate credit to the authors and the source of publication.

Funding: The Ministry of Environment and Forests (MoEF), Government of India.

Competing Interest: The authors declare no competing interests.

Acknowledgements: We are thankful to G.V. Subramanian and Naseem Ahmad (MoEF) for financial support; R. Sundararaju (PCCF \& Chief Wildlife Warden) and Srinivas R. Reddy (District Forest Officer) for permission to work in the forest area and logistic support, and P.A. Azeez, G. Srinivas and other colleagues at the Sálim Ali Centre for Ornithology and Natural History (SACON) Coimbatore, for encouragement and support at various levels. We thank S. Babu of SACON for helping us in preparing the study area map.

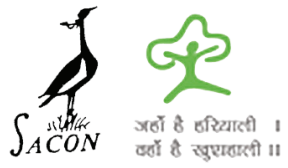

The publication of this article is supported by the Critical Ecosystem Partnership Fund (CEPF), a joint initiative of I'Agence Française de Développement, Conservation International, the European Commission, the Global Environment Facility, the Government of Japan, the MacArthur Foundation and the World Bank. 
been made to study the reptiles of this area (Bhupathy et al. 2009; Chandramouli \& Ganesh 2010). In the present paper, we update the reptile fauna of Meghamalai area and provide data on species richness, composition, distribution with respect to Indian biogeographic zones and their threat status.

\section{Methods}

Meghamalai $\left(9^{0} 30^{\prime}-10^{0} 30^{\prime} \mathrm{N} \& 77^{\circ}-78^{\circ} 30^{\prime} \mathrm{E}\right)$ is located in Theni Forest Division (Theni District) of Tamil Nadu state (Fig. 1). Herpetofauna of the area was studied by Sálim Ali Centre for Ornithology and Natural History (SACON) during 2006-2008, wherein reptiles were sampled in three belt transects $\left(21 \mathrm{~km}^{2}\right.$; Bhupathy et al. 2009; Fig. 1) using quadrat, and time constrained visual encounter survey (TCVES) protocols (Campbell \& Christman 1982; Crump \& Scott 1994) on seasonal basis during day-light hours. However, specimen collection was not done due to non-availability of permits. An inventory of reptile fauna of the area was made based on historic collections and reviews (Boulenger 1891; Smith 1949a,b; Hutton 1949; David \& Vogel 1998; Hutton \& David 2009) and findings of recent studies (Bhupathy et al. 2009, 2011; Chandramouli \& Ganesh 2010). Nomenclature followed herein is of Das (2003), Whitaker \& Captain (2008) and Aengals et al. (2011).
Distribution analysis for the species recorded from Meghamalai was carried out following the biogeography zone categorization of India proposed by Rodgers \& Panwar (1998): Trans-Himalaya, Himalaya, Indian Desert, Semi-Arid, Western Ghats, Deccan Peninsula, Gangetic Plain, Coasts, Northeastern India and Islands. The numerical status of each species was assigned based on the number of observations (Not observed $=0$, Rare $=<5$ observations, Uncommon $=6-20$ and Common $=$ $>20$ observations) and relative abundance (number of observations of a species/total number of observations of all species $X 100$ ) of reptiles were determined based on field data generated during December 2006November 2008 (Bhupathy et al. 2009). Categorization of the threat status of reptiles of the area was based on Conservation Assessment and Management Plan workshop of the IUCN protocol (Molur \& Walker 1998).

\section{Results}

\section{Species Richness}

Available reports showed the occurrence of 90 species of reptiles belonging to 53 genera and 14 families in Meghamalai and its environs. This included two species (2.2\%) of turtles and tortoises, 28 (31.1\%) lizards and 60 (66.7\%) species of snakes. The most diverse reptile family in terms of number of genera and

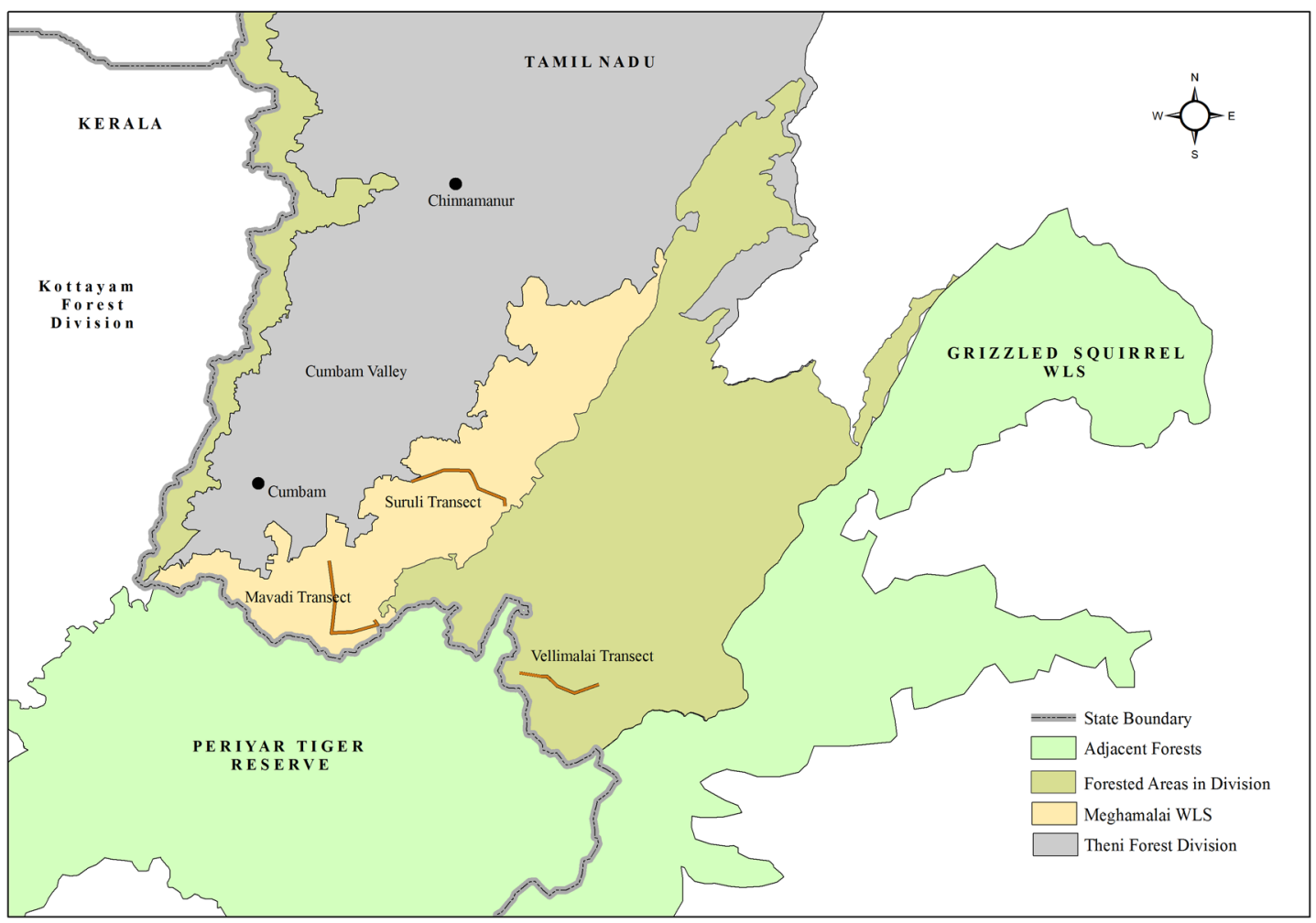

Figure 1. Map showing Meghamalai and adjacent areas of the Theni Forest Division, Tamil Nadu 
species was Colubridae (Table 1). Among lizards, the highest number of species was contributed by the family Gekkonidae (10 species) followed by Agamidae (9). With respect to snakes, the highest number of species was contributed by Colubridae (32) followed by Uropeltidae (12 species). In all, six reptile families were represented by only one species (Table 1 ).

\section{Distribution}

Among the reptiles reported from Meghamalai, 30 species $(33.3 \%)$ were endemic to the Western Ghats. This included the highest of $11 / 12$ (91.7\%) species belonging to the family Uropeltidae. Reptiles of this area shared distribution with all biogeographic zones of the country barring Trans-Himalaya (Fig. 2). The highest of $61 / 90(67.8 \%)$ species were found in Deccan Peninsula followed by Coasts $(36,40 \%)$. This area shared only four (4.4\%) species with Islands found within Indian territorial waters. However, 48 (53.3\%) species had distribution restricted to two biogeographic zones (Fig. 3). Only a fourth of the reptile species reported from Meghamalai had a wide distribution in 7-9 biogeographic zones of the country.

\section{$\underline{\text { Status }}$}

Of the 90 species of reptiles reported from Meghamalai (Appendix 1), tortoises and turtles (Indian Star Tortoise Geochelone elegans, Indian Black Turtle

Table 1. Composition of reptiles at family level in Meghamalai landscape, Western Ghats.

\begin{tabular}{|c|l|c|c|c|}
\hline & Family & Genus & Species & $\begin{array}{c}\text { Endemic } \\
\text { species (\%) }\end{array}$ \\
\hline 1 & Testudinidae & 1 & 1 & 0 \\
\hline 2 & Bataguridae & 1 & 1 & 0 \\
\hline 2 & Gekkonidae & 4 & 10 & $2(20)$ \\
\hline 3 & Agamidae & 5 & 9 & $4(44.4)$ \\
\hline 4 & Chamaeleonidae & 1 & 1 & 0 \\
\hline 5 & Scincidae & 4 & 6 & $3(50)$ \\
\hline 6 & Lacertidae & 1 & 1 & 0 \\
\hline 7 & Varanidae & 1 & 1 & 0 \\
\hline 8 & Typhlopidae & 2 & 2 & 0 \\
\hline 9 & Uropeltidae & 4 & 12 & $11(91.7)$ \\
\hline 10 & Boidae & 2 & 2 & 0 \\
\hline 11 & Pythonidae & 1 & 1 & 0 \\
\hline 12 & Colubridae & 17 & 32 & $8(25)$ \\
\hline 13 & Elapidae & 4 & 4 & 0 \\
\hline 14 & Viperidae & 5 & 7 & $2(28.6)$ \\
\hline & Total & 53 & 90 & $30(33.3)$ \\
\hline & & & & \\
\hline
\end{tabular}

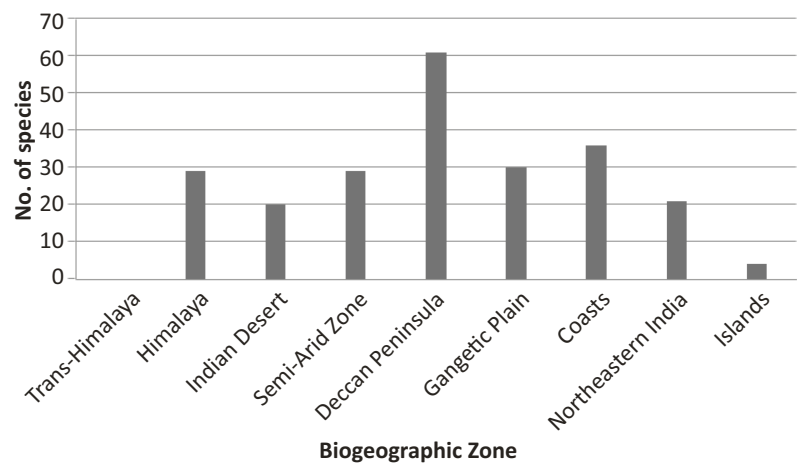

Figure 2. Reptiles reported from Meghamalai area (Western Ghats) sharing distribution with various biogeographic zones of India.

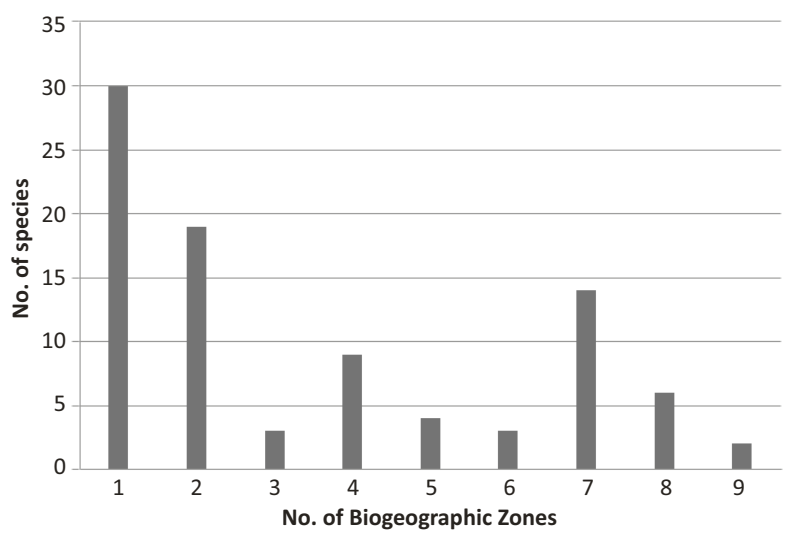

Figure 3. Reptiles reported from Meghamalai (Western Ghats) sharing distribution with number of Biogeographic zones of India.

Melanochelys trijuga) were not reported earlier from the area, but only found recently. Among 28 species of lizards reported, 10 were (numerically) rare and 11 were common (Fig. 4). The Blue-bellied Tree Skink reported from the area was not observed since its first report (1949) from this hill range. Among the 60 species of snakes reported, only three (5\%) were common and 31 species (52\%) were rare (i.e., $<5$ individuals observed in three years). Several species of snakes were numerically rare compared to lizards (Figs. $4 \& 5$ ).

During recent field (2006-2008), 3,374 records of 55 species of reptiles were obtained in TCVES and quadrat sampling; 3004 reptiles in 3600 hours of TCVES and 370 reptiles in 12 ha of quadrat sampling, which empirically worked out to 0.83 reptiles/man hour of search and 30.8 reptiles/ha respectively. Only 10 species had relative abundance $\geq 1 \%$. This typically included nine species of lizards and one snake (Hump-nosed Pit Viper Hypnale hypnale). The relative abundance of Bronze Grass Skink Eutropis macularia was the highest (34.7\%) followed by a species of Day Gecko Cnemaspis sp1. (18.6\%) and 


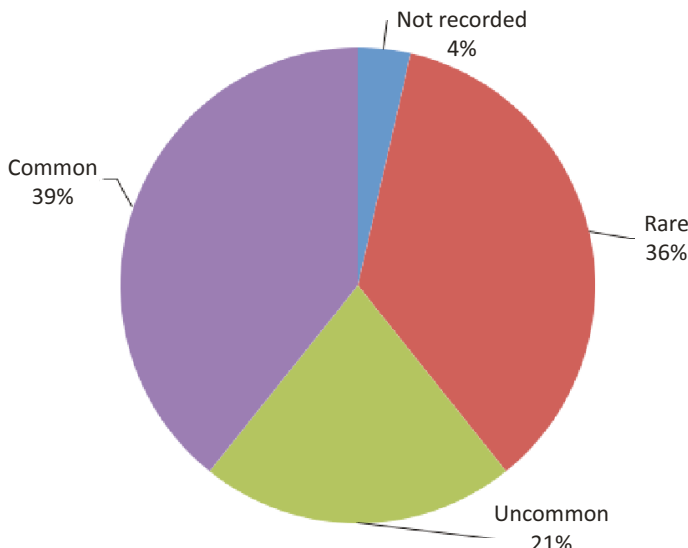

Figure 4. Status of lizards ( $\mathbf{N}=\mathbf{2 8}$ species) observed in Meghamalai during 2006-2008 based on number of observations (Not observed $=0$, Rare $=<5$, Uncommon $=6-20$, Common $=>20$ observations $)$.

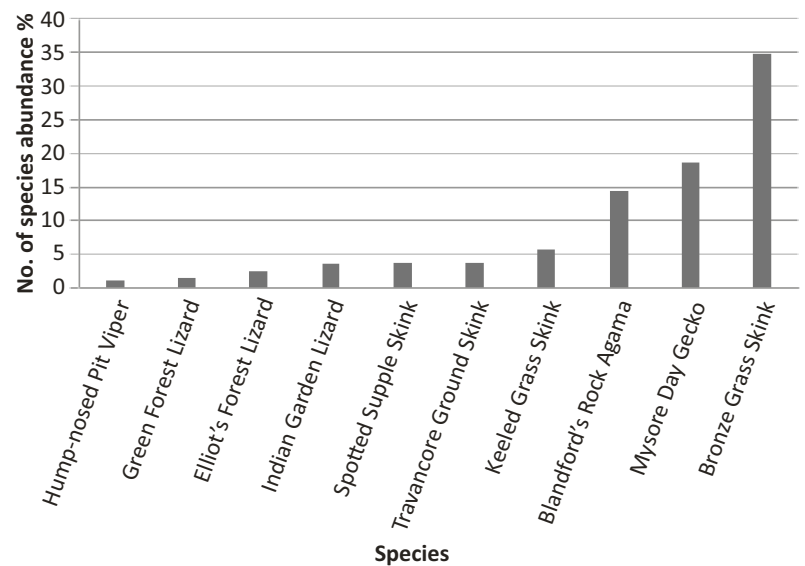

Figure 6. Relative abundance of 10 most common species of reptiles observed in Meghamalai, Western Ghats during 2006-2008.

Blanford's Rock Agama Psamophilus blanfordanus (Fig. 6).

Highly threatened species of Meghamalai included two 'Critically Endangered' (Hutton's Pit Viper, Dindigal Shieldtail Uropeltis cf. dindigalensis) which were not sighted in the present study and eight 'Endangered' species (Appendix 1). Four species were considered as 'Data Deficient'. In all, only $16(18 \%)$ species were categorized as 'Lower Risk- Least Concerned' (Fig. 7).

\section{Discussion}

A record of 90 species of reptiles including two subspecies of Coelognathus helena (C.h. helena, C.h. monticollaris) in Meghamalai, is the highest number of species reported so far for any specific landscape of the

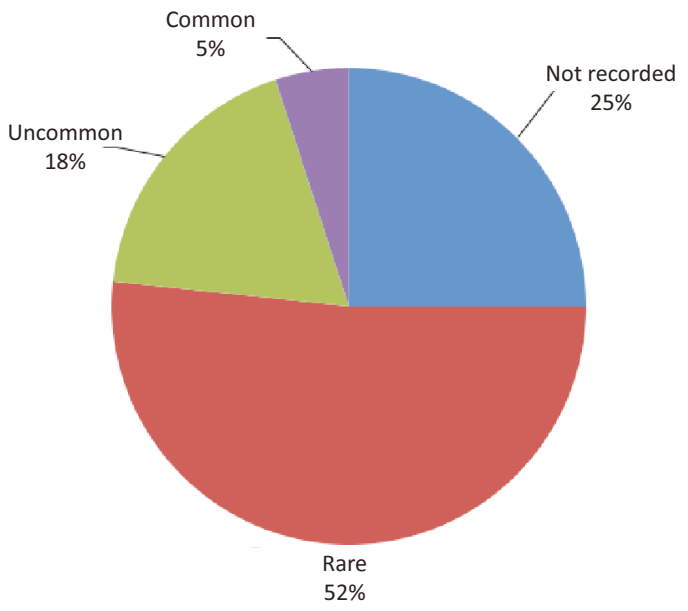

Figure 5. Status of snakes ( $\mathrm{N}=60$ species) observed in Meghamalai during 2006-2008 based on number of observations (Not observed $=0$, Rare $=<5$, Uncommon $=6-20$, Common $=>20$ observations )

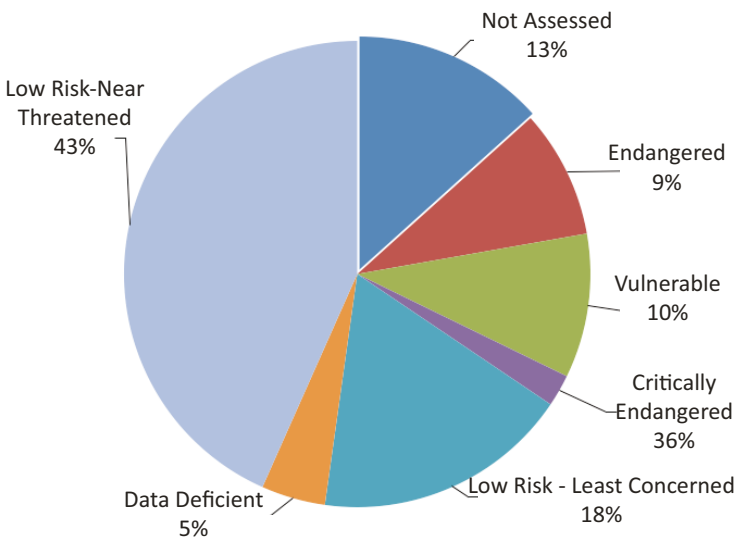

Figure 7. Threat status of reptile species reported from Meghamalai, Western Ghats (based on Molur \& Walker 1998).

Western Ghats. As both the subspecies of Coelognathus helena were found in the same location (i.e., sympatric), we tentatively considered them distinct species in the present analysis. We suggest further studies to determine the taxonomic status of the subspecies of Coelognathus helena. A compilation by Aengels et al. (2011) showed the occurrence of 518 reptile species in India, and Das (1996) reported 165 species from the Western Ghats. The present report of 90 species is about $17.4 \%$ of reptiles of the country and about $54.5 \%$ of species of the Western Ghats. Based on a review, Bhupathy (2004) reported 177 species of reptiles from Tamil Nadu State and the present report of 90 species (50.8\%) from Meghamalai alone shows the conservation importance of the area. High species richness in the area is due to 
its broader elevation width, various climatic conditions, and the presence of windward and leeward sides and occurrence of a variety of forest types (Bhupathy et al. 2009,2012). Records of species such as sand boas Gongylophis conicus and Eryx johnii, Saw-scaled Viper Echis carinatus, Fan-throated Lizard Sitana ponticerina as well as Anaimalai Spiny Lizard Salea anamallayana, shieldtails, Uropeltis spp. and Large-scaled Pit Viper Trimeresurus macrolepis from Meghamalai (Srinivas et al. 2008; Bhupathy et al. 2009) indicate the continuum from dry to wet (thorn-dry deciduous- moist deciduousevergreen-montane shola grasslands) forests in the landscape.

Among the 90 species of reptiles reported from Meghamalai, 30 species (33.3\%) were endemic to the Western Ghats. This is much lower compared to the reported endemism (53.3\%) of the reptiles of the Western Ghats (Das 1996). Occurrence of endemic species such as Ashambu Shieldtail Uropeltis liura, Periyar Shieldtail Uropeltis arcticeps madurensis, Hutton's Pit Viper and Blue-bellied Tree Skink in Meghamalai is poorly known even today. Hutton's Pit Viper is apparently endemic to the area, but has not been observed since its description despite intensive surveys in recent years (Bhupathy et al. 2009; Chandramouli \& Ganesh 2010). Boulenger (1891) described the Blue-bellied Skink based on a specimen from Bodanaikanur (now Bodinayakanur, a part of the present Theni Forest Division). Further, this species was reported from Meghamalai by Smith (1949a) though no report of this species is available since then. It was considered endemic to this hill range till its recent collection from over ca. $600 \mathrm{~km}$ (straight-line distance) northwards, in Kudremukh National Park, Karnataka (Harikrishnan et al. 2012).

The higher sharing of fauna of Meghamalai with that of the Deccan Peninsula and Coasts might be due to a similarity in bio-climate and habitats of these landscapes. However, no commonality was found with respect to the reptile fauna between Meghamalai and the Trans-Himalaya. Difference in the age, geological position, and variation in elevation, climate and perhaps the distance between these landscapes might have led to distinct reptile assemblages. It is to be noted that 48 species (53.3\%) of reptiles found here were restricted to only one or two biogeographic zones of the country (Fig. 3). This shows that the reptiles of the Western Ghats (Meghamalai) are highly vulnerable to habitat alterations and climate change, if any.

Several species of reptiles found in Meghamalai were numerically rare, and 16 of them (one lizard species and 15 snakes) were not observed in recent studies
(Bhupathy et al. 2009; Chandramouli \& Ganesh 2010), which were reported earlier (Boulenger 1891; Hutton 1949; Hutton \& David 2009). Tortoises and turtles and most of the species of lizards observed have been recorded for the first time from the area. However, Meghamalai lies within the distribution range of many of these newly recorded species (Smith 1931, 1935, 1943; Das 1995; Whitaker \& Captain 2008). Comparison of past (Hutton 1949 reviewed recently in Hutton \& David 2009) and recent data (Bhupathy et al. 2009; Chandramouli \& Ganesh 2010) showed the occurrence of 60 species of snakes in the area; 22 species were common to both past and recent studies, 15 only to the earlier and 23 to the latter respectively. Land use and land cover changes between the historical and recent studies could have possibly led to a local extinction of several species that might have contributed to the above disparity. According to Blatter \& Hallberg (1917), this area was covered with dense montane rain forests during the early $20^{\text {th }}$ century. However, presently, most parts of the landscape along 1000-1500 m have been altered for commercial plantations.

As can be expected, a higher number of snake species was (numerically) rare when compared to lizards (Figs. 4-6) and only one species of snake got a place in the top 10 relatively common reptiles of Meghamalai. This might be due to their difference in trophic and spatial niches occupied by these species (most of the snakes are predators and lizards are insectivores). Species such as the Bronze Grass Skink, a species of Day Gecko Cnemaspis sp.1 and Blanford's Rock Agama are specific to microhabitats such as forest floor with leaf litter, trees with larger trunk and open rocks respectively (Daniel 2002). Availability of suitable microhabitats in Meghamalai could have resulted in their higher abundance here.

Among the 'Critically Endangered' species of Meghamalai, Hutton's Pit Viper has not been sighted since its description (Smith 1949b), despite serious attempts to locate the species since then (Bhupathy et al. 2009; Chandramouli \& Ganesh 2010; but see Boundy 2008). Similarly, the Blue-bellied Tree Skink has not been reported from Meghamalai since 1949 (Harikrishnan et al. 2012). Extensive field work in the region by Bhupathy et al. (2009) and Chandramouli \& Ganesh (2010) did not locate the aforesaid species, and we doubt their continued existence in Meghamalai. As mentioned earlier, changes in land use might have taken a toll on these and several other species. Despite all these taxonomic uncertainties and doubtful occurrence of obscure endemic forms, this landscape is undoubtedly 
one of the most important reptile areas of India. It is hoped that habitat alterations and degradation of this landscape will be under control as a portion of the area comes under the recently declared Meghamalai Wildlife Sanctuary (Tamil Nadu Government Gazette 2009). Collection-based studies on reptiles would provide more insights on faunal distribution of the area (Ganesh et al. in press) and potentially reduce the disparity in the number of species observed in the area during the $1940 \mathrm{~s}$ and in recent years (2006-2008).

\section{REFERENCES}

Aengals, R., V.M.S. Kumar \& M.J. Palot (2011). Updated Checklist of Indian Reptiles. Zoological Survey of India, Kolkata, India, www. zsi.gov.in/checklist/Checklist\%20of\%20Indian\%20Reptiles.pdf (downloaded on 22 July 2013).

Bhupathy, S. (2004). Reptiles, pp. 62-75. In: Annamalai, R. (ed.). Tamil Nadu Biodiversity Strategy and Action Plan - Chordate Diversity. Tamil Nadu Forest Department, Chennai.

Bhupathy, S., G. Srinivas \& N. Sathishkumar (2009). A study on the Herpetofaunal communities of the Upper Vaigai Plateau, Western Ghats, India. Final Report submitted to the Ministry of Environment and Forests, Government of India. Sálim Ali Centre for Ornithology and Natural History, Coimbatore, 75pp.

Bhupathy, S., G. Srinivas, N. Sathishkumar, T. Karthik \& A. Madhivanan (2011). Herpetofaunal mortality due to vehicular traffic in the Western Ghats, India: a case study. Herpetotropicos 5(2): 119-126.

Bhupathy, S., G. Srinivas, N. Sathishkumar, M. Murugesan, S. Babu, R. Suganthasakthivel \& P. Sivakumar (2012). Diversity and conservation of selected biota of the Meghamalai landscape, Western Ghats. India. Current Science 102(4): 590-595.

Blatter, E. \& F. Hallberg (1917). Preliminary notes on a recent botanica tour to the High Wavy Mountain (S. India). Journal of the Bombay Natural History Society 25(2): 290-292.

Boulenger, G.A. (1891). Description of a new species of lizard obtained by Mr. H.S. Ferguson in Travancore, Southern India. Journal of the Bombay Natural History Society 6(4): 449.

Boundy, J. (2008). A possible third specimen of the pitviper genus Tropidolaemus from India. Hamadryad 32 (1): 59-62.

Campbell, H.W. \& S.P. Christman (1982). Field techniques for Herpetofaunal Community Analysis, pp. 193-200. In: Scott, N.J. Jr. (ed.). Herpetological Communities. Wildlife Research Report 13. U. S. Department of Interior, Fish and Wildlife Service, Washington, D.C.

Chandramouli, S.R. \& S.R. Ganesh (2010). Herpetofauna of southern Western Ghats, India - reinvestigated after decades. Taprobanica 2(2): 72-85; http://dx.doi.org/10.4038/tapro.v2i2.3145

Crump, M.L. \& N.J. Scott (1994). Visual encounter survey. pp. 8496.In: Heyer, W.R., M.A. Donnelly, R.W. Mcdiarmid, L.C. Hayek \& M.S. Foster (eds.). Measuring and Monitoring Biological Diversity, Standard Methods for Amphibians. Smithsonian Institution Press. USA.
Daniel, J.C. (2002). The Book of Indian Reptiles and Amphibians. Oxford University Press, Mumbai, India, 238pp.

Das, I. (1995). Turtles and Tortoises of India. WWF-India/Oxford University Press, Bombay, 195pp.

Das, I. (1996). Biogeography of the Reptiles of South Asia. Krieger Publishing Company, Malabar, Florida.

Das, I. (2003). Growth of knowledge on the reptiles of India, with an introduction to systematics, taxonomy and nomenclature. Journal of the Bombay Natural History Society 100(2\&3): 446-501.

David, P. \& G. Vogel (1998). Redescription of Trimeresurus huttoni, Smith, 1949 (Serpents, Crotalinae), with a discussion of its relationships. Hamadryad 22(2): 73-87.

Ganesh, S.R., S. Bhupathy, P. David, N. Sathishkumar \& G. Srinivas (in Press). Snake Fauna of High Wavy Mountains, Western Ghats, India: Species Richness, Status and Distribution Pattern. Russian Journal of Herpetology..

Harikrishnan, S., K. Vasudevan, A. de Silva, V. Deepak, N.B. Kar, R. Naniwadekar, A. Lalremruata, K.R. Prasoona \& R.K. Aggarwal (2012). Phylogeography of Dasia Gray, 1830 (Reptilia: Scincidae), with the description of a new species from southern India. Zootaxa 3233: 37-51.

Hutton, A.F. (1949). Notes on the snakes and mammals of the High Wavy Mountains, Madura District, south India. Part I-Snakes. Journal of the Bombay Natural History Society 48: 454-460.

Hutton, A.F. \& P. David (2009). Notes on a collection of snakes from south India, with emphasis on the snake fauna of the Meghamalai Hills (High Wavy Mountains). Journal of the Bombay Natural History Society 105: 299-316.

Molur, S. \& S. Walker (1998). Note book for Reptiles. CAM P. CBSG South Asian Reptile Special Interest Group / South Asian Reptile Network, Taxon Data Sheets from the Reptiles of India Report, $226 \mathrm{pp}$.

Rodgers, W.A. \& H.S. Panwar (1998). Wildlife Protected Areas in India - Vol. 1. Wildlife Institute of India, Dehradun, 341pp.

Smith, M.A. (1931). The Fauna of British India, Ceylon and Burma, including the whole of the Indo-Chinese subregion. Reptilia and Amphibia. Vol. I. Testutines. Taylor \& Francis, London.

Smith, M.A. (1935). The Fauna of British India, including Ceylon and Burma. Reptilia and Amphibia - Vol. II. Sauria. Taylor and Francis, London, 440pp.

Smith, M.A. (1943). The Fauna of British India, Ceylon and Burma, including the whole of the Indo-Chinese subregion. Reptilia and Amphibia. Vol. III, Serpentes. Taylor \& Francis, London, 583pp.

Smith, M.A. (1949a). Notes on a second specimen of the skink Dasia subcaerulea from south India. Journal of the Bombay Natural History Society 48: 596-597.

Smith, M.A. (1949b). A new species of pit viper from South India: Trimeresurus huttoni sp. nov. Journal of the Bombay Natural History Society 48(3): 596.

Srinivas, G., S. Bhupathy \& A. Madhivanan (2008). Occurrence of Salea anamallayana Beddome, 1878 in High Wavy Mountains, Western Ghats. Journal of the Bombay Natural History Society 105(3): 193-194.

Tamil Nadu Government Gazatte (2009). Declaration of Meghamalai Wildlife Sanctuary. Regd. No. TN/CCN/467/2009-11: 322-325.

Whitaker, R. \& A. Captain (2008). Snakes of India - The Field Guide. Draco Books, Chennai, 385pp. 
Appendix 1. Reptiles of Meghamalai and their status.

\begin{tabular}{|c|c|c|c|c|c|c|}
\hline & Common name & Scientific name & $\begin{array}{c}\text { Global } \\
\text { distribution }\end{array}$ & $\begin{array}{l}\text { Threat } \\
\text { status }\end{array}$ & $\begin{array}{l}\text { Numerical } \\
\text { status }\end{array}$ & Reference \\
\hline 1 & Indian Star Tortoise & Geochelone elegans & $\mathrm{NE}$ & VU & $\mathrm{R}$ & 7 \\
\hline 2 & Indian Black Turtle (Image 1) & Melanochelys trijuga & $\mathrm{NE}$ & LR-NT & $\mathrm{R}$ & 3 \\
\hline 3 & Day Gecko & Cnemaspis sp.1 & $\mathrm{EI}$ & NA & C & 3 \\
\hline 4 & Ornate Day Gecko & Cnemaspis ornata & $\mathrm{E}$ & VU & $\mathrm{R}$ & 3 \\
\hline 5 & Day Gecko & Cnemaspis sp. 2 & $\mathrm{E}$ & NA & $\mathrm{R}$ & 3 \\
\hline 6 & Kollegal Ground Gecko & Geckoella collegalensis & El & $\mathrm{DD}$ & UC & 3 \\
\hline 7 & Brooke's House Gecko & Hemidactylus cf. brookii & $\mathrm{NE}$ & LR-LC & $\mathrm{R}$ & 3 \\
\hline 8 & Asian House Gecko & Hemidactylus frenatus & $\mathrm{NE}$ & LR-LC & C & 3 \\
\hline 9 & Bark Gecko & Hemidactylus leschenaultii & $\mathrm{NE}$ & LR-LC & UC & 3 \\
\hline 10 & Spotted Rock Gecko & Hemidactylus maculatus & El & LR-LC & $\mathrm{R}$ & 3 \\
\hline 11 & Termite-hill Gecko (Image 2) & Hemidactylus triedrus & NE & LR-LC & $\mathrm{R}$ & 3 \\
\hline 12 & Oceanic Worm Gecko & Hemiphyllodactylus aurantiacus & $\mathrm{El}$ & Vu & UC & 3 \\
\hline 13 & Fan-throated Lizard & Sitana ponticeriana & $\mathrm{NE}$ & LR-LC & $\mathrm{R}$ & 3 \\
\hline 14 & Western Ghats Flying Lizard & Draco dussumieri & $\mathrm{E}$ & LR-NT & UC & 3 \\
\hline 15 & Anaimalai Spiny Lizard & Salea anamallayana & $\mathrm{E}$ & EN & $\mathrm{R}$ & 3 \\
\hline 16 & Indian Garden Lizard & Calotes versicolor & $\mathrm{NE}$ & LR-NT & C & 3 \\
\hline 17 & Large-scaled Forest Lizard & Calotes grandisquamis & $\mathrm{E}$ & LR-NT & $\mathrm{R}$ & 3 \\
\hline 18 & Green Forest Lizard (Image 3) & Calotes calotes & $\mathrm{NE}$ & LR-NT & C & 3 \\
\hline 19 & Roux's Forest Lizard & Calotes rouxii & El & LR-NT & UC & 3 \\
\hline 20 & Elliiot's Forest Lizard & Calotes ellioti & E & LR-NT & C & 3 \\
\hline 21 & Blandford's Rock Agama & Psammophilus blanfordanus & $\mathrm{NE}$ & NA & C & 3 \\
\hline 22 & South Asian Chamaeleon & Chamaeleo zeylanicus & $\mathrm{NE}$ & VU & $\mathrm{R}$ & 3 \\
\hline 23 & Spotted Supple Skink & Lygosoma punctata & $\mathrm{NE}$ & LR-LC & C & 3 \\
\hline 24 & Blue-bellied Tree Skink & Dasia subcaeruleum" & $\mathrm{E}$ & $\mathrm{DD}$ & NR & 5 \\
\hline 25 & Beddome's Grass Skink & Eutropis beddomei & E & NA & $\mathrm{R}$ & 3 \\
\hline 26 & Keeled Grass Skink & Eutropis carinata & NE & NA & C & 3 \\
\hline 27 & Bronze Grass Skink & Eutropis macularia & $\mathrm{NE}$ & NA & C & 3 \\
\hline 28 & Travancore Ground Skink & Scincella travancoricum & $\mathrm{E}$ & VU & C & 3 \\
\hline 29 & Leschenault's Lacerta (Image 4) & Ophisops leschenaulti & $\mathrm{El}$ & LR-LC & C & 3 \\
\hline 30 & Bengal Monitor Lizard & Varanus bengalensis & $\mathrm{NE}$ & Vu & UC & 3 \\
\hline 31 & Brahminy Worm Snake & Ramphotyhlops braminus & NE & LR-NT & C & 3 \\
\hline 32 & Beaked Worm Snake & Grypotyphlops acutus & NE & NA & $\mathrm{R}$ & 3 \\
\hline 33 & Pied-belly Shieldtail & Melanophidium punctatum & $\mathrm{E}$ & VU & $\mathrm{R}$ & 1,3 \\
\hline 34 & Perrotet's Shieldtail & Plecturus perroteti & E & LR-LC & NR & 1 \\
\hline 35 & Red-bellied Shieldtail & Rhinophis sanguineus & $\mathrm{E}$ & $\mathrm{DD}$ & NR & 1 \\
\hline 36 & Travancore Shieldtail & Rhinophis travancoricus & $\mathrm{E}$ & $\mathrm{DD}$ & NR & 1 \\
\hline 37 & Kerala Shieldtail & Uropeltis ceylanica & $\mathrm{E}$ & LR-LC & NR & 1 \\
\hline 38 & Elliot's Shieldtail & Uropeltis ellioti & El & LR-NT & NR & 1 \\
\hline 39 & Palni Shieldtail & Uropeltis pulneyensis & $\mathrm{E}$ & EN & NR & 1 \\
\hline 40 & Red-spotted Shieldtail & Uropeltis rubromaculatus & $\mathrm{E}$ & EN & NR & 1 \\
\hline 41 & Ashambu Shieldtail & Uropeltis liura ${ }^{\#}$ & $\mathrm{E}$ & EN & NR & 6 \\
\hline 42 & Dindigul (?) Shieldtail & Uropeltis cf. dindigalensis & $\mathrm{E}$ & $C R$ & NR & 2 \\
\hline 43 & Black-bellied Shieldtail & Uropeltis woodmasoni & $\mathrm{E}$ & EN & NR & 4 \\
\hline 44 & Periyar Shieldtail & Uropeltis arcticeps madurensis" & $\mathrm{E}$ & LR-NT & $\mathrm{R}$ & 2,3 \\
\hline
\end{tabular}




\begin{tabular}{|c|c|c|c|c|c|c|}
\hline & Common name & Scientific name & $\begin{array}{c}\text { Global } \\
\text { distribution }\end{array}$ & $\begin{array}{l}\text { Threat } \\
\text { status }\end{array}$ & $\begin{array}{l}\text { Numerical } \\
\text { status }\end{array}$ & Reference \\
\hline 45 & Rock Python & Python molurus & NE & LR-NT & $\mathrm{R}$ & 1,3 \\
\hline 46 & Common Sand Boa & Gongylophis conicus & NE & NA & $\mathrm{R}$ & 3 \\
\hline 47 & Red Sand Boa & Eryx johnii & NE & LR-LC & $\mathrm{R}$ & 3 \\
\hline 48 & Gunther's Vine Snake & Ahaetulla dispar & $\mathrm{E}$ & LR-NT & UC & $1,2,3$ \\
\hline 49 & Common Vine Snake & Ahaetulla nasuta & NE & LR-NT & UC & 2,3 \\
\hline 50 & Bronze-headed Vine Snake & Ahaetulla perroteti & E & EN & $\mathrm{R}$ & 1,3 \\
\hline 51 & Brown Vine Snake & Ahaetulla pulverulenta & NE & LR-NT & $\mathrm{R}$ & 1,3 \\
\hline 52 & Banded Racer & Argyrogena fasciolata & NE & LR-NT & NR & 1 \\
\hline 53 & Ceylon Cat Snake & Boiga ceylonensis & $\mathrm{NE}$ & NA & $\mathrm{R}$ & 1,2 \\
\hline 54 & Collared Cat Snake & Boiga nuchalis & NE & LR-NT & $\mathrm{R}$ & 3 \\
\hline 55 & Common Cat Snake & Boiga trigonata & NE & LR-LC & $\mathrm{R}$ & 3 \\
\hline 56 & Yellow-Green Cat Snake & Boiga flaviviridis & $\mathrm{EI}$ & NA & $\mathrm{R}$ & 3 \\
\hline 57 & Ornate Flying Snake & Chrysopelea ornanta & NE & LR-NT & UC & 3 \\
\hline 58 & Common Trinket Snake & Coelognathus helena helena & NE & NA & $\mathrm{R}$ & 3 \\
\hline 59 & Montane Trinket Snake & C. h. monticollaris & $\mathrm{E}$ & NA & $\mathrm{R}$ & $1,2,3$ \\
\hline 60 & Common Bronzeback Tree Snake & Dendrelaphis tristis & NE & LR-LC & $\mathrm{R}$ & 3 \\
\hline 61 & Bridel Snake & Dryocalamus nympha & NE & VU & $\mathrm{R}$ & 1,3 \\
\hline 62 & Lesser Stripe-necked Snake & Liopeltis calamaria & NE & LR-NT & UC & 3 \\
\hline 63 & Common Wolf Snake & Lycodon aulicus & $\mathrm{NE}$ & LR-LC & $\mathrm{R}$ & 3 \\
\hline 64 & Barred Wolf Snake & Lycodon striatus & NE & LR-NT & $\mathrm{R}$ & 3 \\
\hline 65 & Travancore Wolf Snake & Lycodon travancoricus & $\mathrm{El}$ & LR-NT & UC & $1,2,3$ \\
\hline 66 & Common Kukri Snake & Oligodon arnensis & $\mathrm{NE}$ & LR-LC & $\mathrm{R}$ & 3 \\
\hline 67 & Striped Kukri Snake & Oligodon brevicauda & $\mathrm{E}$ & LR-NT & $\mathrm{R}$ & 1,3 \\
\hline 68 & Russell's Kukri Snake & Oligodon taeniolatus & NE & LR-NT & UC & 1,3 \\
\hline 69 & Travancore Kukri Snake & Oligodon travancoricus & El & EN & $\mathrm{R}$ & 1,2 \\
\hline 70 & Black Spotted Kukri Snake & Oligodon venustus & E & LR-NT & $\mathrm{R}$ & 2 \\
\hline 71 & Indian Rat Snake & Ptyas mucosa & $\mathrm{NE}$ & LR-NT & UC & $1,2,3$ \\
\hline 72 & Dumeril's Black-headed Snake & Sibynophis subpunctatus & $\mathrm{El}$ & LR-NT & $\mathrm{R}$ & 3 \\
\hline 73 & Gunther's Narrow-headed Snake & Xylophis stenorhynchus" & E & EN & NR & 6 \\
\hline 74 & Beddome's Keelback & Amphiesma beddomei & E & LR-NT & $\mathrm{R}$ & $1,2,3$ \\
\hline 75 & Hill Keelback & Amphiesma monticola & E & Vu & $\mathrm{R}$ & 3 \\
\hline 76 & Striped Keelback (Image 5) & Amphiesma stolatum & $\mathrm{NE}$ & LR-NT & UC & 1,3 \\
\hline 77 & Olive Keelback & Atretium schistosum & NE & LR-NT & NR & 1 \\
\hline 78 & Green Keelback & Macropisthodon plumbicolor & NE & LR-NT & C & $1,2,3$ \\
\hline 79 & Checkered Keelback & Xenochrophis piscator & NE & LR-LC & $\mathrm{R}$ & $1,2,3$ \\
\hline 80 & Common Krait & Bungarus caeruleus & NE & LR-NT & $\mathrm{R}$ & 3 \\
\hline 81 & Striped Coral Snake & Calliophis nigrescens & $\mathrm{EI}$ & LR-NT & $\mathrm{R}$ & $1,2,3$ \\
\hline 82 & Spectacled Cobra & Naja naja & $\mathrm{NE}$ & LR-NT & $\mathrm{R}$ & 1,3 \\
\hline 83 & King Cobra & Ophiophagus hannah & NE & LR-NT & NR & 1 \\
\hline 84 & Russell's Viper & Daboia russelii & $\mathrm{NE}$ & LR-NT & UC & 1,3 \\
\hline 85 & Saw-scaled Viper & Echis carinatus & $\mathrm{El}$ & LR-NT & UC & 3 \\
\hline 86 & Hump-nosed Pit Viper (Image 6) & Hypnale hypnale & NE & LR-NT & C & 2,3 \\
\hline 87 & Bamboo Pit Viper & Trimeresurus gramineus & $\mathrm{EI}$ & LR-NT & NR & 1 \\
\hline 88 & Large-scaled Pit Viper & Trimeresurus macrolepis & El & LR-NT & $\mathrm{R}$ & $1,2,3$ \\
\hline 89 & Malabar Pit Viper & Trimeresurus malabaricus & E & LR-NT & UC & $1,2,3$ \\
\hline
\end{tabular}




\begin{tabular}{|c|l|l|c|c|c|c|}
\hline & Common name & Scientific name & $\begin{array}{c}\text { Global } \\
\text { distribution }\end{array}$ & $\begin{array}{c}\text { Threat } \\
\text { status }\end{array}$ & $\begin{array}{c}\text { Numerical } \\
\text { status }\end{array}$ & Reference \\
\hline 90 & Hutton's Pit Viper & Tropidolaemus huttoni ${ }^{\#}$ & $\mathrm{E}$ & $\mathrm{CR}$ & $\mathrm{NR}$ & 1 \\
\hline
\end{tabular}

\# = Meghamalai landscape is type locality

Global distribution: NE - Non endemic to India, EI - Endemic to India, E - Endemic to Western Ghats

Threat status: CR - Critically Endangered, E - Endangered, VU- Vulnerable, LR/NT - Lower Risk Near Threatened, LR/LC - Lower Risk Least Concerned, DD - Data Deficient, NA - Not Assessed (Molur \& Walker 1998)

Numerical status: R - Rare, UC - Uncommon, C - Common; NR - Not Recorded

Reference: 1 - Hutton \& David (2009), 2 - Chandramouli \& Ganesh (2010), 3 - Bhupathy et al. (2009), 4 - Hutton (1949), 5 - Boulenger (1891), 6 - Smith (1943), 7 - S. Babu pers. comm.

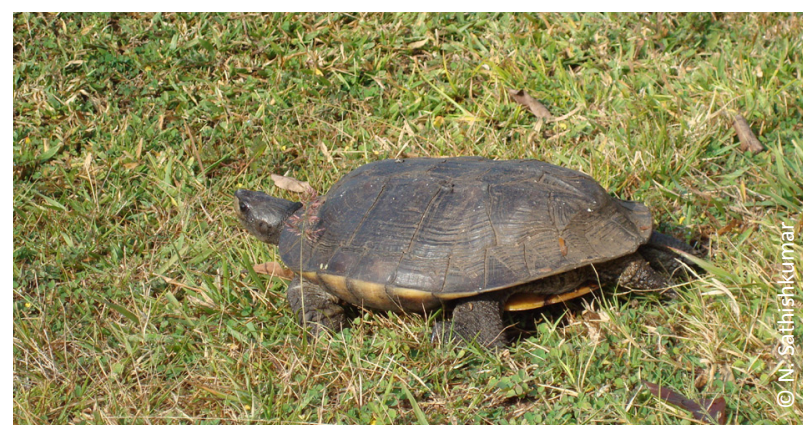

Image 1. Indian Black Turtle

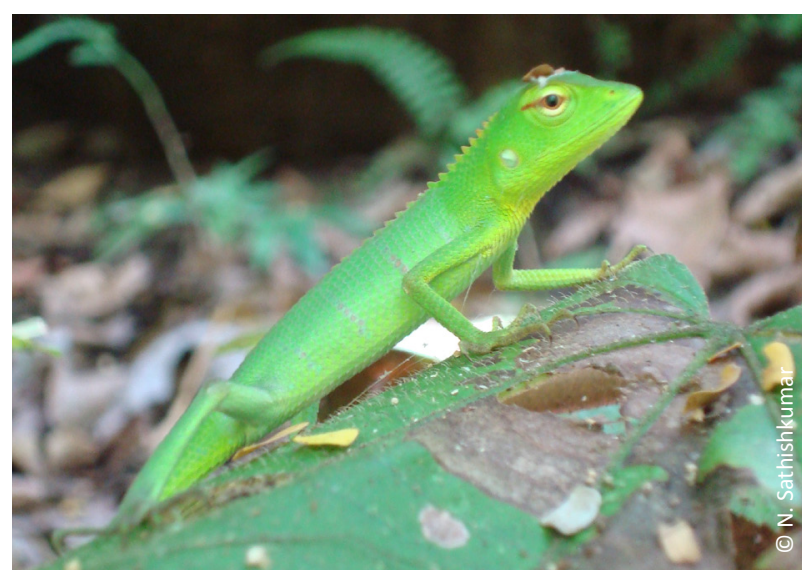

Image 3. Green Forest Lizard

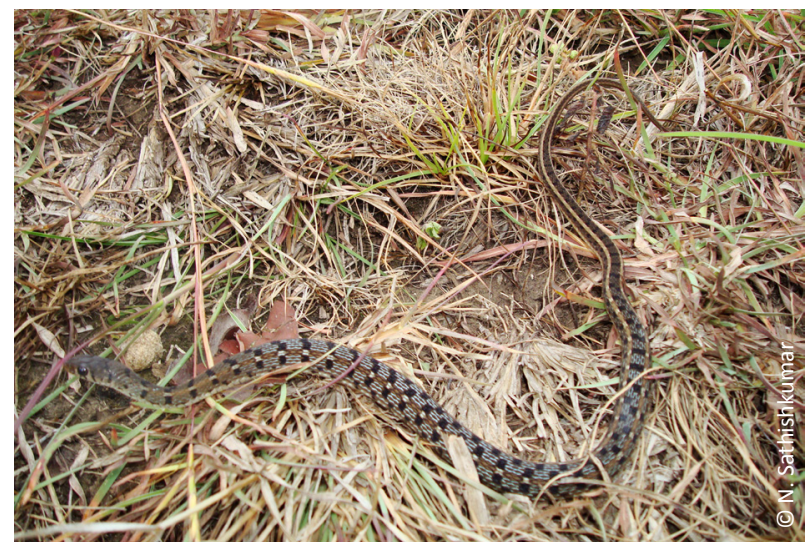

Image 5. Striped Keelback

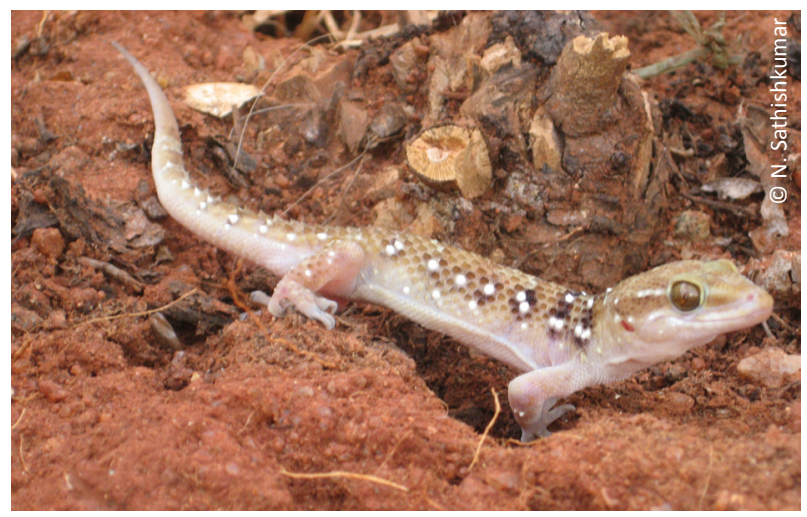

Image 2. Termite-hill Gecko

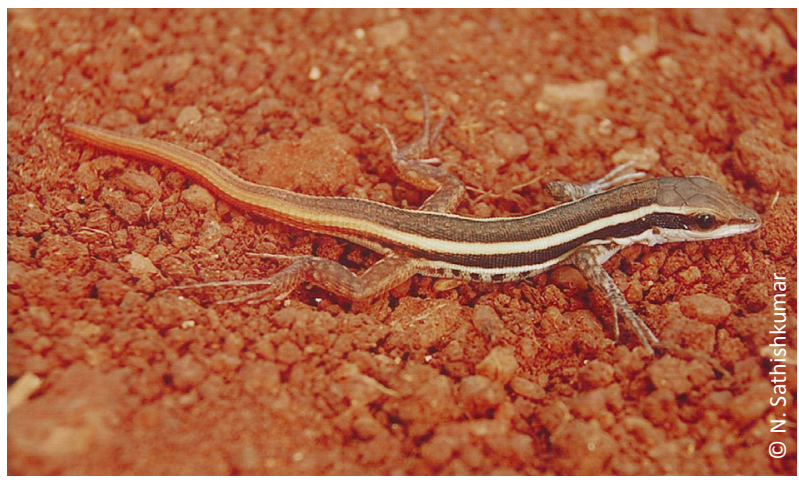

Image 4. Leschenault's Lacerta

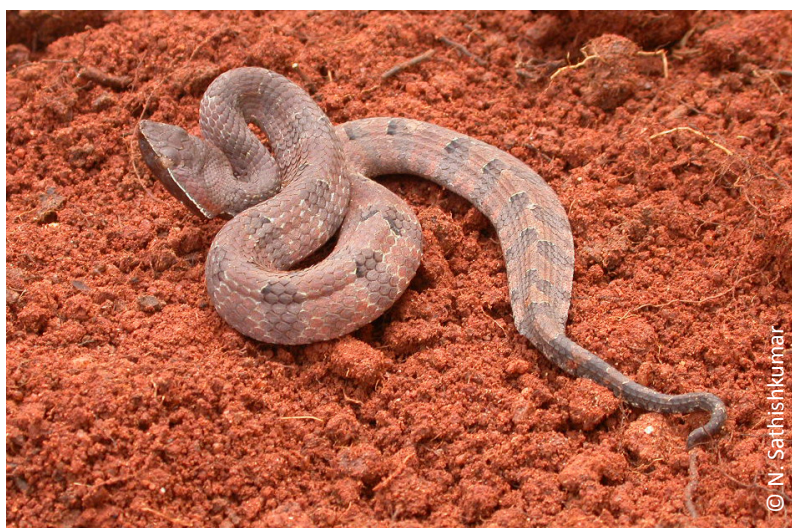

Image 6. Hump-nosed Pit Viper 